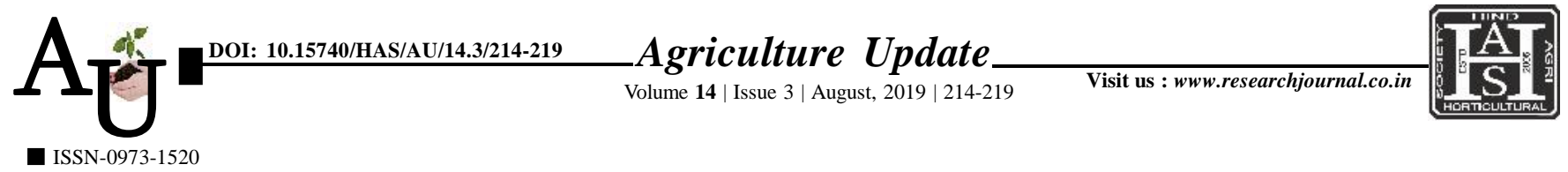

\title{
Research Article: Impact of national horticulture mission (NHM) on socio-economic status of turmeric growers
}

\author{
Y. S. Dhruw, H. K. Awasthi and M. A. Khan
}

Article Chronicle: Received :

12.06.2019;

Revised :

04.07.2019;

Accepted :

15.07.2019

KEY Words :

National horticulture mission, Socio-

economic status, Turmeric growers

SUMMARY : The present study was carried out during the years 2015-16 and 2016-17 in Chhattisgarh plains. The aim of this study was to know the impact of NHM on socio-economic status of turmeric growers. A total of 320 farmers ( 160 beneficiaries and 160 non-beneficiaries) were selected randomly. Data collection was done by the use of interview schedule through personnel interview. The collected data was analyzed with the help of suitable statistical methods. The findings reveal that majority of the beneficiaries $(56.88 \%)$ belonged to middle class, whereas non-beneficiaries, 50.52 per cent of the respondents belonged to lower middle class.

How to cite this article : Dhruw, Y.S., Awasthi, H.K. and Khan, M.A. (2019). Impact of national horticulture mission (NHM) on socio-economic status of turmeric growers. Agric. Update, 14(3): 214-219; DOI : 10.15740/ HAS/AU/14.3/214-219. Copyright@ 2019: Hind Agri-Horticultural Society. 